\title{
S5ynthesis
}

International Scientific Conference of IT and Business-Related Research

\section{IMPROVEMENT OF THE PROCESS OF SCHOOL PRINCIPALS' PROFESSIONAL DEVELOPMENT IN THE FIELD OF MANAGEMENT}

\author{
UNAPREĐENJE PROFESIONALNOG RAZVOJA DIREKTORA ŠKOLA \\ U OBLASTI MENADŽMENTA \\ Snežana Đorđević ${ }^{1}$, Jasmina Vesić Vasović2, Miroslav Radojičić 2 Zoran Nešić \\ ${ }^{1}$ Sveti Sava Primary School, Batočina, Serbia \\ ${ }^{2}$ University of Kragujevac, Faculty of Technical Sciences in Čačak, 65 Svetog Save, Čačak, Serbia
}

\begin{abstract}
:
The aim of the research is to examine the professional development of school principals with the aim of more efficient organizing of their training in the field of management. The research is related to the professional development and the professional growth of the primary school principals in Šumadija, Pomoravlje and Raška districts. Research results indicate insufficient additional education of school principals for the role of the manager they perform; as well as the marginal role of professional development in increasing school principals' competence. To that end, the paper indicates that the professional development process should be designed according to the needs of school principals, the specific and current problems of the working environment, that is, the professional development of school principals should unite work and professional improvement with the use of practical knowledge.
\end{abstract}

\section{Key words:}

educational management, professional development, competence of school principals.

\section{INTRODUCTION}

In order to make changes at school, a school principal must be appropriately prepared, since educational reforms are ongoing processes which are so significant that they are related to the school survival and prosperity. That is why a leader must be flexible towards others, towards society and the environment in which he or she lives.

School principal is a manager and a leader too. As a manager, school principal performs that function independently or in cooperation with associates or the entire collective. As a leader, one must be self-critical first, in order to change others. The visionary in leading people is an important determinant of a school principal as a leader. Only when a school principal builds capacity for constant changing can he or she rule the changes.

The system of school principals' professional development or better yet (dis) order of that system is a subject to criticism. Based on international experience, quality assurance advisers in Educational Administration have made the Manual for self-assessment and evaluation of school work, which provided guidelines on how to check the quality of school work and proposed activities that would contribute to it. The school is expected to improve work and to take care of the professional development of teaching and non-teaching staff. This Manual includes specific requirements for school management, as well as the fact that a school leader should "own professional knowledge and organizational skills. He or she should be regularly trained in the

\section{Apstrakt:}

Cilj istraživanja prikazanog u ovom radu jeste da ispita profesionalni razvoj direktora škola u cilju efikasnije organizacije obuke direktora iz oblasti menadžmenta. Istraživanje se odnosi na profesionalni rast i razvoj direktora osnovnih škola u oblastima Šumadija, Pomoravlje i Raška. Rezultati istraživanja ukazuju da je dodatno obrazovanje direktora škola za funkciju menadžera koju obavljaju nedovoljno; kao i da je uloga profesionalnog razvoja u kompetenciji direktora sasvim marginalna. U tom smislu, ovaj rad dalje ističe da bi proces profesionalnog razvoja trebalo da bude osmišljen u skladu sa potrebama direktora škola, specifičnim i aktuelnim problemima njihovog radnog okruženja - drugim rečima profesionalni razvoj direktora škola trebalo bi da spaja rad i usavršavanje, uz korišćenje praktičnog znanja.

\section{Ključne reči:}

menadžment u obrazovanju, profesionalni razvoj, kompentencija direktora škole.

field of organization and management. There is a plan at school about his or her professional development, a report on the implementation and other records. His or her work and behaviour serves as an example to everyone at school and contributes to the reputation of the school." (Manual for self-assessment and evaluation of school work, 2005, p. 108)

School development is inconceivable without the school principals' professional development and without development of their competence (Fullan, 2010; Leithwood, 1992; MendeyzMorse, 1992; NAESP, 2001). The school principal is expected to take an active role in the process of professional development, to be an agent of change, the creator of his or her own professional development and training.

\section{THE EXPERIENCE OF EUROPEAN COUNTRIES WITH PROFESSIONALISING SCHOOL PRINCIPALS}

The strength and development of the school system of individual states are identified, among other things, by caring about educational and professional development of school employees. When it comes to school principals, the situation in European countries is very different. This is demonstrated by the study on education and school principals' professional development in the function of their professionalization, created within the European Network for Improving and Development in Educational Management - ENIRDEM (Verbiest, 2001). 
Programs for education and school principals' training which are carried out by 15 institutions in 12 EU countries were analysed as a part of this research. In most countries such programs are called School / Educational Management Programs. In some countries, e.g. Finland or Norway, term Guidance in Education is used for such programs, while some other countries call them Programs for School Principals, etc. (Verbiest, 2001).

Most programs are implemented by higher education institutions for teaching professions. Sometimes these institutions/ faculties connect with other institutions in order to find the staff that would be most suitable for the quality implementation of the school principals' training programs. In one case, the government is the founder of the institution for the school principals' professional development (Slovenia), and in the other case the founder is the professional association (Czech Republic). In most cases, experts outside of the institutions which implement the program are included as creators of program contents.Most often those are experts in particular management disciplines (e.g. human resource management, development management, decision-making, etc.) and experienced experts from practice (school principals, advisers, etc.)

Intensive professionalization of school principals in countries in which programs have been implemented for more than 15 years can be attributed to the significant changes in the social and political context of schools, as well as the increased demands imposed on schools by their environment. Some institutions justify the introduction of programs by the need of school principals to improve their knowledge in the area of school management, which would enable them to manage school more rationally and more effectively. In some countries, educational policy initiated the beginning of the program, considering it a direct contribution to improving the quality of school work. Some countries make the completion of these programs and obtainment of license a prerequisite for assuming a certain work position. Financial motives are not negligible too, for completion of some of the programs significantly increases the salary of school principals. Higher education institutions, however, earn higher incomes by encouraging and introducing the programs, and also have closer cooperation with schools whose staff they train. By reviewing the European countries' experience in the professionalization of school principals, we can conclude that all countries have accepted the same goal toward which they are moving at an accelerated pace, but in consistence with their views and traditions. Thereat it is possible to observe how many of them are intensively working in this field, conducting research and applying current knowledge.

School principals' professional development in the analysed countries is not only the concern of the Ministry. Many various competent institutions are included in it. School principals' associations have the leading role in the professional development of school principals. By raising the professional competence of its members, these associations build their own reputation, and thus become a respectable factor in school systems of developed countries.

\section{RESEARCH METHODOLOGY}

The subject of this research relates to the professional development and the professional growth of the primary school principals in Šumadija, Pomoravlje and Raška Districts and in that sense it is focused on the dimensions of school principals' training for the manager role and on the role of professional development in increasing school principals' competence.

The aim of the research was to analyze the professional development of school principals and find guidelines for profes- sional development that will contribute to the school principals' performance.

The hypothesis of the research is: the existing programs of formal and non-formal education and vocational training are aligned with the needs and expectations of school principals' profession as managers and leaders and they offer practical knowledge and skills needed in everyday work of school principals.

The practical implications of the research results, the questions and tasks would be to define the competence necessary for successful school management, as well as the creation of programs for improving professional growth, development, and training of school principals that will reflect their needs.

Analysis of the professional development and school principals' training in this paper was carried out by means of qualitative research, which is based on the methods and techniques of research paradigm. A questionnaire was composed to collect the information on school education and topics significant for educational policy, i.e. running, organization, management and control of school work. The research was implemented in 2014 and it included the directors of primary schools in Šumadija, Pomoravlje and Raška Districts.

The first part of the questionnaire is related to studying the attitudes and experiences of school principals in connection with their previous formal education, professional training, and the second part is related to the obstacles to the development of their professional competence and involvement in the professional development process. Questions used in the questionnaire were of an open-ended or close-ended type, and provided the possibility of examinees to create answers independently or to agree with some of the options. The research emphasis is on understanding and perception of reality from the perspective of a school principal who is a key factor, the so-called leader of changes (Fullan, 2002) in school context, responsible for the quality of work and the accomplished school results.

\section{RESEARCH RESULTS ANALYSIS}

The research sample included 69 primary school principals in Šumadija, Pomoravlje and Raška Districts in Serbia - 34 school principals from Šumadija District ((Municipality of Kragujevac, Aranđelovac, Topola, Knić, Lapovo, Rača and Batočina), 27 school principals from Pomoravlje District (Municipality of Svilajnac, Jagodina, Despotovac and Paraćin) and 8 school principals from Raška District (Municipality Novi Pazar and Raška). The results show that only one school principal had 20 years of service, being in the fifth term of office, so the largest part of the sample $-34.9 \%$ - mainly consisted of school principals who were in the first term of office (from 1 to 4 years). $26.9 \%$ of the school principals were in the second term of office (from 4 to 8 years). 15 school principals $-23.8 \%$ - were in the third term of office, having been in the position of a school principal for 8 to 12 years. $12.7 \%$ of school principals were in the fourth term of office, from 16 to 20 years. More than half of the sample included the school principals aged 41 - 50 years, all females (Table 1 ).

\subsection{RELATIONSHIP BETWEEN SCHOOL PRINCIPALS AND THEIR FORMAL EDUCATION}

The structure of surveyed school principals' sample shows their diversity according to criteria such as initial education, age, years of service as a school principal, which indicates their differences in competence. Most school principals - $44.8 \%$ of the sample - acquired the appropriate academic education in 


\begin{tabular}{|c|c|c|c|c|c|}
\hline Years of work as a school & $\%$ & Age & $\%$ & Gender & $\%$ \\
\hline $1-4$ & 35 & $20-30$ & 0 & Female & 53.6 \\
\hline $4-8$ & 26.9 & $31-40$ & 20.3 & Male & 46.4 \\
\hline $8-12$ & 23.8 & $41-50$ & 56.5 & & \\
\hline $12-16$ & 12.7 & $51-60$ & 20.3 & & \\
\hline More than 16 & 1.6 & Over sixty & 2.9 & & \\
\hline
\end{tabular}

Table 1. The structure of the sample

class teaching by finishing Faculties of Education and Teacher Training Faculties, thus obtaining the necessary pedagogical education for teaching. A number of school principals - 17.9\% of the sample - acquired the appropriate academic education by finishing the faculty in the field of natural sciences (Biology, Mathematics, and Chemistry), technical sciences (Technology and IT education) or Faculty of Physical education. 19.4\% of this sample were school principals whose initial education was in the field of social sciences (Serbian language, History, Geography, Pedagogy and Special Education).

Out of all examinees, postgraduate education was acquired by $17.2 \%$ ( $1 \mathrm{PhD}, 5$ Magisters, 5 with master's degree, and 1 with master specialization), and only half of these school principals acquired education for the school principal's work (administration, management) throughout their educational process.

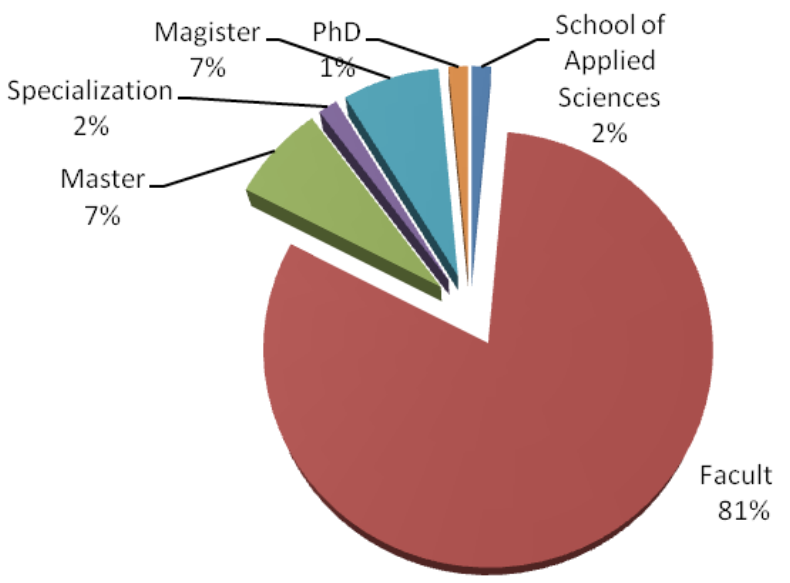

Figure 1. The level of school principals' education

As far as the school principals' experience in connection with their formal education is concerned, their opinions of whether their formal education included the guidance on administrative management of school or program/course for school principals, that is, whether they were prepared for the position of a school principal prior to taking the position, were examined. The results show that only one school principal (2\%) had prepared for the job before taking office and that almost half of school principals (48\%) have never prepared for school management, either before or during the term of office as a school principal. Examinees classified the acquisition of competence in the framework of formal educational institutions as relatively low.

People are competing for better results in all fields of work (higher quality products, better services, higher incomes, etc.). Thus, changes in education are encouraged, innovations are introduced, and reforms are implemented, with the aim of achieving better pedagogical and educational results. Thereat, the role of a school principal is the leading role because it is believed that school principals can provide good performance of schools and students, similarly as managers in other industries can contribute to the success of their companies.

Successful realisation of managerial positions in the school is conditioned by various influences. School principals who have the appropriate competence, who invest in personal professionalism and who know how to coordinate and direct school development based on a shared vision will act more successfully in that diversity (Staničić, 2005).

Due to such importance of school principals, attention is focused on raising the level of their competence, training prior to assuming managerial functions and training after the appointment. This tends to ensure their level of professionalism that will guarantee the successful realisation of the school vision and goals.

The size, stratification and level of competency a contemporary school principal needs to have in order to meet his or her demanding role successfully, can be obtained from various forms of training - before being appointed and from professional training after that. Almost half of the school principals included in our study have had no training for the school principal role either before or during the term of office. That is devastating and supports the fact that the centralised school administration has affirmed the criterion of obedience and loyalty of school principals to the ruling bureaucracy, as a measure of their quality.

\subsection{PARTICIPATION OF SCHOOL PRINCIPALS IN PROFESSIONAL DEVELOPMENT ACTIVITIES DESIGNED FOR THEM}

The research is further focused on the school principals' participation in professional development activities which are designed for them in order to develop their individual professional skills and knowledge.

As for the activities that develop individual and professional skills and knowledge of school principals in research activities or mentoring, as many as $86.6 \%$ of school principals have not been involved in research activities, and $13.4 \%$ of school principals were mentored or took part in them. $52.2 \%$ of school principals attended conferences, courses or seminars in order to observe rather than participate. The value of this approach is that school principals bring their problems and experiences to the process of qualifying, and actively learn from each other and from the examples of good practice. $43.1 \%$ of school principals use this type of professional development.

School principals are very reserved when it comes to didactical offers of learning through seminars and training sessions, believing that their freedom of decision-making regarding time and content is limited, that is, that structured learning arrangements do not respect their individual needs (Adrevski, 2014). School principals' answers indicate that they acquire their professional competence on their own initiative, by self-organized 
activities, outside of educational institutions. It also appears that they have acquired their professional, personal and social skills during their working life (by working in school), and not within some educational engagement. School principals evaluate knowledge and learning offers based on how application oriented they are, they want knowledge and information that are current and helpful for overcoming the problems at workplace, which means the knowledge that is appropriate and oriented towards the precisely set performance targets. Knowledge without practical orientation is an unnecessary burden to them, they want to learn in relation to the concrete situation and specific need, and therefore, they prefer learning for current and foreseeable challenges in the world of work and their school milieu.

\subsection{THE REASONS THAT LEAD TO OBSTACLES TO PROFESSIONAL DEVELOPMENT OF SCHOOL PRINCIPALS}

The next part of the research was related to the causes that lead to obstacles to the professional development of school principals and according to school principals the major obstacle is that professional development is too expensive and thus inaccessible and that they have no incentive to participate in professional development.

When asked to what extent they agreed with the aforementioned obstacles to their professional development, most examinees $(63.8 \%)$ answered that insufficient prerequisites for a school principal - insufficient qualifications, experience and age - were not the obstacles. A large number of school principals (59.4\%) said that the obstacle to their professional development was that professional development was too expensive and therefore unavailable. The reason why school principals do not invest in their professional development does not lie in the fact that it is not planned; this was stated by $81.2 \%$ of school principals. Family responsibilities to the majority of school principals $89.9 \%$ were not an obstacle to their professional development either. $58 \%$ of school principals disagreed with the statement that there were no suitable offers for professional development. The claim that there is no encouragement for participation in professional development activities was approved by $65.2 \%$ of school principals.

Bearing in mind the significant differences in school principals' competence, which are determined by their professional education acquired during undergraduate studies, structure, and years of their working experience, it is clear that their educational needs will have the decisive influence on professional development. Hypothesis that existing programs of formal and non-formal education and professional development are aligned with the needs and expectations of the school principals' profession as managers and leaders and that they offer practical knowledge and skills needed in everyday work of school principals - was not confirmed.

The research results indicate that the primary school principals in Šumadija, Pomoravlje and Raška Districts have rarely, or even never, received training through the professional development programs and in their opinion the main obstacle is that the professional development is too expensive and thus inaccessible and that they have no incentive to participate in it. They also point out that methods of conducting professional development do not provide enough practical knowledge and skills needed for the implementation of school principal's function, which is also a disadvantage. Today, the directors of educational institutions are expected to be constantly confronted with problems and to decide quickly, but the academic contents dominant in the professional development programs do not help them in concrete school environment.

Although these results rely on the subjective assessment of primary school principals in Šumadija, Pomoravlje and Raška Districts, based on which we cannot get general conclusions, they raise issues of general importance in the context of education quality: of (de) motivation of educational institutions' principals to professionally develop in the field of management and thus improve the quality of education and the (un) alignment of content of professional development with the needs and expectations of the school principals profession and the real needs and challenges which schools face today. This conclusion is supported by a large number of papers which present the results of qualitative and quantitative research on efficiency of professional improvement of school principals. (John, 2002; Kartal, 2010; Xu, 2011; Bottoms, O’Neill, Fry \& Hill, 2003). Bottoms, O’Neill, Fry and Hill (2003) point out that the best method of school principals' training is through activities that are based on problemsolving, and elaborate that it is necessary to plan experiential learning in which the candidates will apply knowledge based on research and as a part of solving practical problems in schools, focusing on the basic functions of school, where the candidates will go through internships and learn from well renowned school principals - mentors, within the training process.

\section{CONCLUSION}

Starting with the research results, we can conclude that school principals would be more interested in training if they themselves participated in creating their own development and if they adapted the process to their needs and interests. The largest number of school principals wants the professional development to be realized through seminars and trainings that will be based on the model of experiential learning and the exchange of experiences among participants.

Studies in other countries have shown similar results. Namely, school principals usually point out that they do not respond well to modern methods of professional development, such as the workshop approach, role plays, simulation of the processes, etc. They usually consider this way of training a frivolous game that is not appropriate to their professional development. Bearing this in mind, the question is: Which learning models are the most appropriate for school principals' professional development and how should school principals be motivated to be actively involved in this process?

Based on the research results, we can define the following recommendations for the improvement of school principals' professional development: the process of school principals' training would be most effective if it is implemented through seminars and trainings that are based on the exchange of experiences and models of experiential learning. Most school principals then see themselves as active participants. This data is consistent with the theoretical analysis of the so-called school of the future, in which professional development should be based on cooperation and team work of all the employees at school (school principal, teachers, and expert associates) and models of learning that are adapted to all who participate in it.

School principals would, therefore, be prepared for professional development if seminars were created according to their needs, specific and current problems of the working environment, with the individualisation in the learning process and the optimum conditions for development of cooperative knowl- 
edge. Arrangements for school principals' learning should link work and learning, knowledge of practice should be meaningfully used and the acquired knowledge should be used in practice.

\section{REFERENCES}

Andrevski, M., Arsenijević, J., \& Tomić, M. (2014). Professional development of school directors. Pedagoska stvarnost, 60 (4),692-706.

Bottoms, G., O’Neill, K., Fry, B., \& Hill, D. (2003). Good Principals Are the Key to Successful Schools: Six Strategies to Prepare More Good Principals. Atlanta: Southern Regional Education Board (SREB).

Drucker, F.P. (2002). Veština delotvornog direktora. Novi Sad: Adižes. (In Serbian).

Fullam, M. (2010). Motion Leadership: The skinny on becoming change savvy. Thousand Oak, CA: Corwin Press.

Fullan, M. (2002). The Change Leader. Education Leadership, 59 (8), 16-20.

Goff, P.T., Mavrogordato, M., \& Goldring, E. (2012). Instructional Leadership in Charter Schools: Is There an Organizational Effect or Are Leadership Practices the Result of Faculty Characteristics and Preferences? Leadership and Policy in Schools, 11(1), 1-25.

Hallinger, Ph., \& Snidvongs, K. (2005.) Adding value to School Leadership and Management. Nottingham: National College for School Leadership.

Jonh, P. (2002) The training needs of principals of private schools in the Union Territory of Pondicherry, India. ETD Collection for Fordham University. Paper AAI3056141. Retrieved January 20, 2015, form http//fordham.bepress.com/dissertations/AAI3056141
Kartal, S. (2010). Primary School Principles'Views about Inservise Training Activities. International Journal of Human and Social Sciences, 5(9), 598-603.

Leithwood, K.A. (1992) The move toward transformational leadership. Educational Leadership, 49 (5), 8-12.

McConchie, R. (1998.) Challenges for Educational Leadership in the 21st Century. Retrieved January 20, 2015, form http// icponline.org/disclaimer.htm

Mendez-Morse, S. (1992). Leadership Characteristics that Facilitate School Change. Austin, TX: Southwest Educational Development Laboratory (SEDL).

Ministarstvo prosvete i sporta Republike Srbije. (2005). Pravilnik za samovrednovanje i vrednovanje rada škole. Beograd:MPS.

National Association of Elementary School Principals. (2001). Leading Learning Communities: NAESP Standards for What Principals Should Know and Be Able to Do. NAESP: Alexandria, Virginia.

Radojičić, M., \& Vesić Vasović, J. (2011). Industrijski menadžment. Tehnički fakultet: Čačak. (In Serbian).

Robbins, S., \& Coulter, M. (2005). Menadžment. 8. Izdanje. Beograd: Data Status. (In Serbian).

Staničić, S. (2011). Menadžment u obrazovanju. Gornji Milanovac: Centar za marketing u obrazovanju.

Verbiest, E. (2001). A Cross-European Survey on Training School Leaders: Leading Schools for Learning. Ljubljana: Škola za direktore.

Xu, J. (2011). Primary and Secondary School Principal Training Research Based on Implicit Wisdom. Educate, 1(11), 31-43. 